\title{
Habitat preferences of diurnal raptors in relation to human access to their breeding territories in the Balkan Mountain Range, Bulgaria
}

\author{
Nadejda Djorgova ${ }^{*}$, Dimitar Ragyov, Valko Biserkov, Jordan Biserkov (1) and Boris P. Nikolov@
}

\begin{abstract}
Background: In this study we examined the habitat preferences of three diurnal raptors in relation to human access. We aimed to identify the selection of breeding habitat by the Golden Eagle (Aquila chrysaetos), the Long-legged Buzzard (Buteo rufinus), and the Peregrine Falcon (Falco peregrinus) in response to site accessibility by humans, and in turn, the response of these species to human presence.

Methods: Data about the nest locations were collected. Analyses and maps were created using ArcGIS. The "least cost path" was defined using the Cost Path tool.

Results: The lowest values of the Cost Path were established for Long-legged Buzzard and the highest values were estimated for Golden Eagle. Intermediate Cost Path values for Peregrine Falcon were found.

Conclusions: The Long-legged Buzzard could be considered as the most tolerant to human presence in its breeding territories. The Golden Eagle have the lowest degree of tolerance and the Peregrine Falcon is ranked in an intermediate position compared to the other two species, but closer to Golden Eagle.
\end{abstract}

Keywords: Anthropogenic impact, Golden Eagle, Least cost path, Long-legged Buzzard, Peregrine Falcon

\section{Background}

Raptors are generally used as indicators of anthropogenic effects, as they are higher order predators, long lived, require large territories, and are often sensitive to habitat change (Newton 1979; Russo 2006; Sergio et al. 2006; Carrete et al. 2009). Identifying the factors governing the nesting habitat selection of raptors with high conservation status may be of primary importance in determining the conservation objectives. Environmental variables are often at the forefront of habitat selection studies for raptors however we also need to consider the effect

*Correspondence: djorgova@gmail.com Institute of Biodiversity and Ecosystem Research, Bulgarian Academy of Sciences, 2 Gagarin Street, 1113 Sofia, Bulgaria of anthropogenic factors in influencing habitat selection. Human activities impact the raptors by altering the characteristics of their habitats (Watson 1991, 1992; Xirouchakis 2001; Russo 2006; Whitfield et al. 2007; Demerdzhiev et al. 2014). In many instances human presence in the breeding territories causes disturbance of the pairs, which are particularly sensitive in pre-reproductive and reproductive periods (Tjernberg 1983; Andersen et al. 1990; Watson and Dennis 1992; Alivizatos et al. 1998; Pedrini and Sergio 2001; Redinov 2010; Spaul and Heath 2016, 2017; Perona et al. 2019).

Accessibility for people is an important predictor of direct and indirect human impact on ecosystems (Trombulak and Frisell 2000). Accessibility is determined by the available paths and transport infrastructure, by the 
terrain slope and unevenness, the natural water barriers, and the vegetation permeability. Tourism and recreational activities (e.g. rock climbing, caving, hang gliding and paragliding, and winter sports) are also an important aspect, in terms of how people use the different accessibility areas. Despite the obvious importance of accessibility, its quantification is intricate. Simple measuring of the distance is often used as the easiest quantification of accessibility, which neglects the influence of topography, water features and vegetation. The ArcGIS tools Cost Distance and Cost Path enable a more sophisticated approach to quantifying accessibility by taking into account the slope of the landscape to be traversed. In the context of ecology, "the least cost path" analysis is traditionally employed mainly to assess the functional connectivity of landscapes for species and determine sites that are potentially used as dispersal routes or that should be conserved as biological corridors (Schadt et al. 2002; LaRue and Nielsen 2008; Jobe and White 2009). Accessibility models can be used to analyze the impact of tourism as well as other human impacts on protected areas in order to identify more appropriate management and protection measures (Esteves et al. 2011). They also reduce costs and increase efficiency in conducting environmental studies (Greenwood 1996).

The Golden Eagle (Aquila chrysaetos) (Linnaeus 1758) and the Peregrine Falcon (Falco peregrinus) (Tunstall 1771) were abundant in Bulgaria until the beginning of the twentieth century, with their populations declining thereafter (Simeonov et al. 1990). The Golden Eagle population in Bulgaria is estimated at $120-150$ pairs (Petrov et al. 2015), and the Peregrine Falcon population has been estimated at 200 pairs (Ragyov et al. 2008; Stoyanov et al. 2015). The Long-legged Buzzard (Buteo rufinus) (Cretzschmar 1827) is recorded as a breeding species in Bulgaria, and its breeding population was recently estimated at 800-1000 pairs (Vatev et al. 2015). These species of raptors are common in the Balkan Mountain Range but are of high conservation importance on a national level. All three species are protected by the Bulgarian Biological Diversity Act. The Golden Eagle and Long-legged Buzzard are also listed in the Red Data Book of the Republic of Bulgaria under the category VU-Vulnerable (Petrov et al. 2015; Vatev et al. 2015), while Peregrine Falcon is listed as EN - Endangered (Stoyanov et al. 2015).

Golden Eagle is known to live in various rocky habitats in proximity to open areas is of importance. In Bulgaria, its nests are positioned predominantly on cliffs, but also have been found on trees (Simeonov et al. 1990; Milchew and Georgiewa 1992; Milchev 1994; Petrov et al. 2007).

Long-legged Buzzard resides on cliffs, in stone quarries near deforested mountain slopes or other open spaces, on hilly foothills (Simeonov et al. 1990; Vatev et al. 2015). It is also found near wetlands of various types (Michev et al. 1984; Vatev 1987). Its nests are placed on cliffs, trees and quarries (Boev 1962; Michev et al. 1984; Vatev 1987; Simeonov et al. 1990; Milchev 2009; Demerdzhiev et al. 2014). Peregrine Falcon inhabits rocky terrains, near open spaces, sometimes with scattered trees and patchy woodland. Very rarely, it occurs in settlements (Simeonov et al. 1990; Stoynov et al. 2007, 2015). This species prefers for nesting steep, high cliffs with a dominant position to the landscape, which are found in many areas of its range (Gainzarain et al. 2000; Jenkins 2000; Sergio et al. 2004; Jenkins and van Zyl 2005; Brambilla et al. 2006; Ragyov et al. 2008; Karyakin and Nikolenko 2009).

The European Ecological Network Natura 2000 is a fundamental tool for the conservation of many bird species and their habitats in the European Union, the main purpose of which being to cover the most suitable areas for the survival and reproduction of the target species of birds in protected areas (Fernández and Gurrutxaga 2010). The protected areas (parks and reserves) form the core of the biodiversity conservation in Bulgaria. Studies on the selection of breeding territories by protected raptors in relation to human access to their territories can be helpful in creating effective conservation plans and in the design of protected areas.

We formulated a working hypothesis that accessibility is an important factor in the choice of breeding habitat for Golden Eagle, Long-legged Buzzard and Peregrine Falcon, which can be quantified and used as a reliable indicator in assessing anthropogenic impact. We aim to identify the selection of breeding habitat by the Golden Eagle, the Long-legged Buzzard, and the Peregrine Falcon in response to site accessibility by humans, and to compare the response of these species to human presence.

\section{Methods \\ Study area}

Balkan Mountain Range is the largest mountain range in Bulgaria covering an area of $11,596 \mathrm{~km}^{2}$. Balkan Mountain Range has a length of $530 \mathrm{~km}$ and its width ranges between 15 and $45 \mathrm{~km}$. The average altitude is $722 \mathrm{~m}$, with Botev Peak being the highest point at $2376 \mathrm{~m}$ (Fig. 1). A mountainous variety of the temperate continental climate is predominating in the Balkan Mountain Range. The seasonal precipitation distribution corresponds to the moderate continental retention regime. The forests are mainly deciduous, dominated by European Beech (Fagus sylvatica), Hornbeam (Carpinus betulus), Durmast Oak (Quercus petraea), and with local occurrences of Moesian Beech (Fagus sylvatica moesiaca), Sweet Chestnut (Castanea sativa), Turkey Oak ( $Q$. cerris), and Hungarian Oak (Q. frainetto). The coniferous 


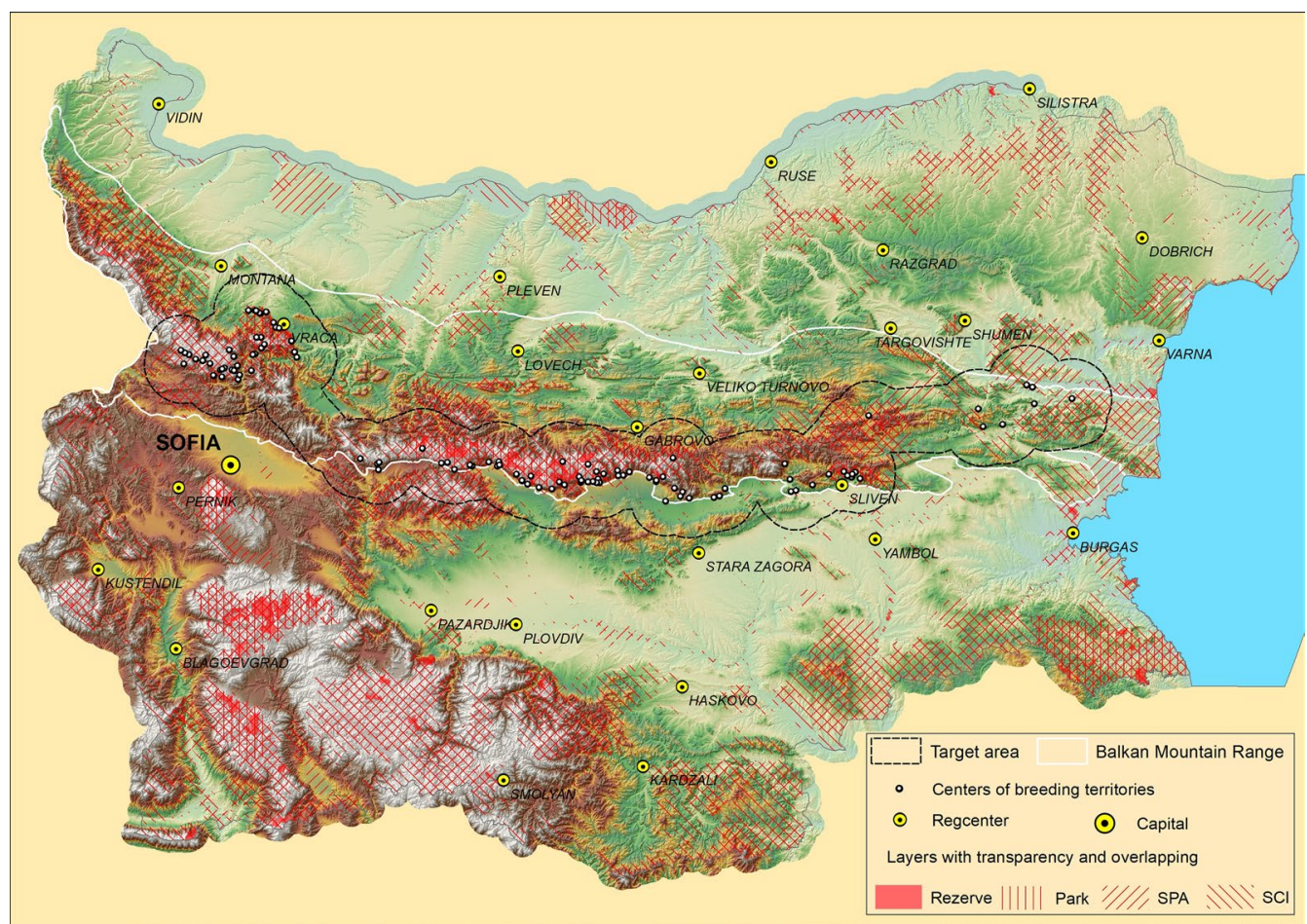

Fig. 1 Map of the study area with the breeding territories of the three species under study recorded

forests do not form a continuous coverage in the mountain. They are represented mostly by Norway Spruce (Picea abies), but Scots Pine (Pinus sylvestris) and Macedonian Pine (Pinus peuce) are also found. Alpine grass vegetation is present in the highest zone (Kopralev 2002). The Balkan Mountain Range is a biodiversity rich region for fauna. Forest habitats maintain the majority of the faunal biodiversity, but alpine regions also contribute to the biodiversity of the area (Gruev and Kuzmanov 1994). Part of the territory of the study area is included in the European Ecological Network Natura 2000 and Protected Areas, which are presented in Fig. 1.

\section{Field work}

Data collection on the location of Golden Eagle, Longlegged Buzzard and Peregrine Falcon nests within the territory of the Balkan Mountain range took place between March and July during the period 2006-2010. Prior to the study, potential nesting sites such as cliff formations and solitary cliffs were identified based on reports of previous cases of nesting. Also, a survey of topographic maps and maps of Google Earth ${ }^{\mathrm{TM}}$ was performed. Potential locations were explored from an optimal distance, depending on the field conditions. The terrain was scanned using binoculars with a laser rangefinder and a spotting scope. The centers of the breeding territories were determined either based on nests found or indirectly based on birds' behavior. GPS device, binoculars' laser rangefinder, and a compass were also used. In some cases, the exact location of the nest was not possible to be fixed due to topographic features and/or risk of unnecessary disturbance to the birds. However, most of these cases were related to single-standing small cliffs and the exact position of the nest was estimated within an acceptable error of up to $10-20 \mathrm{~m}$. A total of 38 territories (29 localized nests) of Golden Eagle, 54 territories (38 nests) of Long-legged Buzzard and 20 territories (6 nests) of Peregrine Falcon were identified (Fig. 1).

\section{GIS analyses}

The analyses and maps were created using ArcGIS 10.6 (ESRI, Redlands, CA, USA).

\section{Input layers}

Input layers are presented in Table 1.

\section{Cost Distance and Cost Path tools}

In this study, we regarded accessibility as an integral characteristic which is inversely proportional to the effort that people have to make to reach a certain point. Accessibility of certain point (e.g. center of the breeding territory) is determined from a given starting point 
Table 1 Input layers

\begin{tabular}{|c|c|c|}
\hline Name of layer & Modifications & Original source \\
\hline Centers of breeding territories & Point layer created by GPS coordinates & Authors'field data \\
\hline Settlements & Point layer created by GPS coordinates & JICA_Core_DB.mdb \\
\hline Roads & $\begin{array}{l}\text { Line layer created after detailing by use of topo- } \\
\text { graphic map JICA_DB_TopoMap_2500 }\end{array}$ & JICA_Core_DB.mdb/T_BgRoad \\
\hline Starting point on the Roads & $\begin{array}{l}\text { Point layer created by points obtained after } \\
\text { calculating of the shortest distance between } \\
\text { Centers of breeding territories and Roads }\end{array}$ & $\begin{array}{l}\text { Roads (modified) and Centers of breeding ter- } \\
\text { ritories }\end{array}$ \\
\hline Lodges & $\begin{array}{l}\text { Point layer created by GPS coordinates from } \\
\text { several specialized portals }\end{array}$ & $\begin{array}{l}\text { www.bulgarian-mountains.com; www.btsbg.org/; } \\
\text { http://www.tourism-bg.net/; https://www.plani } \\
\text { nite.info/; https://opoznai.bg/; http://www.hiji. } \\
\text { tourism-bg.net/ }\end{array}$ \\
\hline Routes & Tourist routes and trails & $\begin{array}{l}\text { www.bgmountains.org and JICA_Core_DB.mdb/ } \\
\text { T_BgRoad }\end{array}$ \\
\hline Starting point on the Routes & $\begin{array}{l}\text { Point layer created by points obtained after } \\
\text { calculating of the shortest distance between } \\
\text { Centers of breeding territories and Routes }\end{array}$ & Routes and Centers of breeding territories \\
\hline $\begin{array}{l}\text { Religious tourism centers (monasteries and } \\
\text { chapels) }\end{array}$ & $\begin{array}{l}\text { Point layer created by points taken from a topo- } \\
\text { graphic map }\end{array}$ & JICA_DB_TopoMap_25000 \\
\hline Quarries/mines & Point layer created by GPS coordinates & www.mi.government.bg/bg \\
\hline Starting points for rock climbing & Point layer created by GPS coordinates & www.climbingguidebg.com \\
\hline Starting points for hang gliding and paragliding & Point layer created by GPS coordinates & www.skynomad.com \\
\hline Caves & $\begin{array}{l}\text { Point layer created by points taken from a topo- } \\
\text { graphic map }\end{array}$ & JICA_DB_TopoMap_25000 \\
\hline Waterfalls & Point layer created by GPS coordinates & Nikolov (2013) \\
\hline Lift stations & $\begin{array}{l}\text { Point layer created by points taken from a topo- } \\
\text { graphic map }\end{array}$ & JICA_DB_TopoMap_25000 \\
\hline Special Protection Areas (SPA) & - & $\begin{array}{l}\text { N2000_BG_120_ptici_2019.shp } \\
\text { http://natura2000.moew.government.bg/Home/ } \\
\text { Documents }\end{array}$ \\
\hline Sites of Community Importance (SCl) & - & $\begin{array}{l}\text { N2000_BG_234_mestoobitania_2019.shp } \\
\text { http://natura2000.moew.government.bg/Home/ } \\
\text { Documents }\end{array}$ \\
\hline Protected Areas under the Protected Areas Act & - & $\begin{array}{l}\text { zpo_all.shp } \\
\text { http://eea.government.bg/zpo/bg/index_downl } \\
\text { oad.jsp }\end{array}$ \\
\hline Digital Elevation Model (DEM) & $\begin{array}{l}\text { Raster with } 30 \mathrm{~m} \text { pixel size, transformed to } \\
\text { UTM35N and resampled to } 20 \mathrm{~m} \text { pixel size }\end{array}$ & $\begin{array}{l}\text { Shuttle Radar Topography Mission (SRTM) } \\
\text { https://earthdata.nasa.gov/nasa-shuttle-radar- } \\
\text { topography-mission-srtm-version-3-0-global- } \\
\text { 1-arc-second-data-released-over-asia-and-austr } \\
\text { alia }\end{array}$ \\
\hline
\end{tabular}

(e.g. settlement) and is inversely proportional to the sum of the slope along the flattest path between the two. The ArcGIS Cost Path tool was used to calculate "the least cost path" but the application of Cost Distance was needed as a preliminary step. In this case, when using the Cost Distance tool, for each pixel on the map, its slope was counted. The slope is the most important parameter for calculating "the total energy cost" to move from the starting point to the certain point, compared to altitude, exposure, and other parameters in mountain areas in the temperate latitudes and at altitudes up to $2000 \mathrm{~m}$ (Minetti et al. 2002; Jobe and White 2009). First based on an elevation raster a new slope raster is created using
ArcGIS Slope tool. For each pixel, the tool calculates the rate of change in elevation from that pixel to its neighbors in east-west direction ( $x$-axis) and north-south direction $(y$-axis) and uses trigonometry to determine the overall slope in degrees. Finally, the least-cost path from a source to a destination is created. The algorithm works by iteratively expanding the source and destination's neighboring pixels like circular waves and recomputing the least-cost required to reach them given the new wave front.

To calculate the cost distance, depending on the specific task, its formula needs to be adapted to produce a result that can be related to the ecology of the species and the analyzed environmental parameters and factors. In the 
present case, the following initial formula for cost distance was used:

$$
\begin{aligned}
\text { Cost distance }= & \min _{\mathrm{pa}} \sum_{\mathrm{ant}}^{\mathrm{rp}} \text { Slope (input_pixel) } \\
& \times \text { Multiplier (active_population) }
\end{aligned}
$$

where the symbols "pa" means path, "rp" result pixel, and "ant" antropogenic point.

Multiplier is a function of active_population and determines the relationship between cost distance and active population. The relationship between the Multiplier and the active population is inversely proportional. In the simplest case, the relation is described by the $1 / x$ function:

$$
\operatorname{Multiplier}(x)=1 / x
$$

Graphically, it can be depicted as a virtual moving away of anthropogenic objects at a distance inversely proportional to their active population (Fig. 2).

The active population in the present sample was within a range of 1 to 77,411 . In the case of the bigger settlements (population over 10,000), the $1 / x$ function assigned so much importance to the large number of inhabitants that those settlements completely dominated the rest of the settlements in determining the disturbance of the breeding pairs as a result of human presence (using cost distance and cost path). In order to correct that bias and to achieve a more objective impact assessment for multiplier for bigger settlements with population more than 10,000 , it was assumed that with the population exceeding 10,000 residents, disturbance increased negligibly. Hence, a threshold of 10,000 was introduced:

$$
\text { Multiplier }=\frac{1}{\min (\text { active_population, 10,000) }}
$$

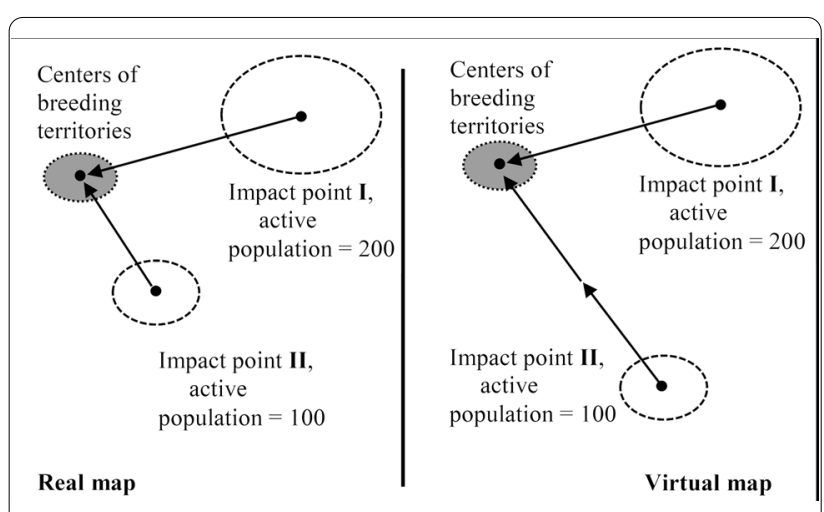

Fig. 2 Scheme of "virtual moving away" of anthropogenic objects
In the sorted sample (without repeats), the ratio $r$ between two consecutive values varied between 1 and 2.5 . In this model, the influence of the sources with the lowest numbers was negligible and it could be disregarded in practice. To achieve a more objective impact assessment, the ratio $r$ needed to be minimised. The effect of the source of impact was omnidirectional and could be considered as a circle (two-dimensional object). The multiplier was a one-dimensional scalar revealing the virtual "distance" from the nest. The most direct relationship between those two was a square root. Thus, the ratio $r$ would vary between 1 and $\sqrt{2.5} \approx 1.58$, and formula (1) was changed accordingly:

$$
\text { Multiplier }=\frac{1}{\sqrt{\text { min (active_population, 10,000) }}}
$$

Formula (2) yielded values in the range of 0.01 to 1 . To obtain values in the range of 1 to 100 , the following formula was used:

$$
\text { Multiplier }=\frac{100}{\sqrt{\min (\text { active_population, 10,000) }}}
$$

When applying formula (3), this reflected in the cost path geometry as an increased likelihood of connecting nearer and smaller settlements to the center of the breeding territory than the cost path obtained without the use of a square root.

In order to make a general analysis to determine the joint disturbance that all anthropogenic objects may cause, their multiplier values must be comparable. In our case, the active population indicator, for which there were accurate data on the settlement's population numbers, was taken as a base. In the cases of incomplete data for other anthropogenic objects and data of indirect origin, values based on expert knowledge were given.

\section{Analyses}

The Cost Path analyses are presented in Table 2. Sample section of the study area presenting the results obtained using Cost Path tool is shown in Fig. 3.

\section{Statistical analyses}

STATISTICA V. 12 (StatSoft Inc. 2014) was used for the statistical analysis of the data. We used Spearman's rank correlation coefficient to determine the presence or absence of correlation. We used descriptive statistics to calculate mean, minimum, maximum and standard deviation of the cost path values of various impact points (anthropogenic objects) for all three species of the raptors under study. Non-parametric 
Table 2 Cost Path analyses

\section{Cost Path analyses}

Cost Path from settlements to the centers of breeding territories ${ }^{a}$

Cost Path from roads to the centers of breeding territories

Cost Path from operating lodges to the centers of breeding territories ${ }^{b}$

Cost Path from pedestrian routes to the centers of breeding territories

Cost Path from religious tourism centers to the centers of breeding territories

Cost Path from operating quarries or mines to the centers of breeding territories

Cost Path from starting points for recreational activities (rocks used for rock climbing, starting points for hang gliding and paragliding, caves, waterfalls, and lifts) to the centers of breeding territories

Cost Path All-Cost Path from any point of an anthropogenic object in the united layer to the centers of the breeding territories

Percentage distribution of breeding territories in relation to Natura 2000 areas_-special Protection Areas (SPA) and Sites of Community Importance (SCI) Percentage distribution of breeding territories in relation to Protected Areas - parks and reserves ${ }^{c}$

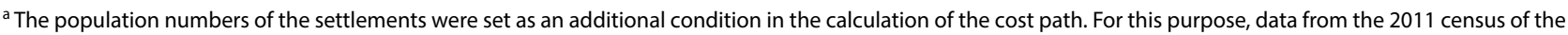
National Statistical Institute (www.nsi.bg) were used, taking into account the number of the active population, which included people aged 5 to 70 years

${ }^{\mathrm{b}}$ The capacity in terms of number of beds in the Balkan Mountains lodges was set as an additional condition in the calculation of the cost path

${ }^{\mathrm{C}}$ In cases where the breeding territory fell simultaneously in the two types of Protected Areas, the Protected Area with a higher status was predominantly taken into account

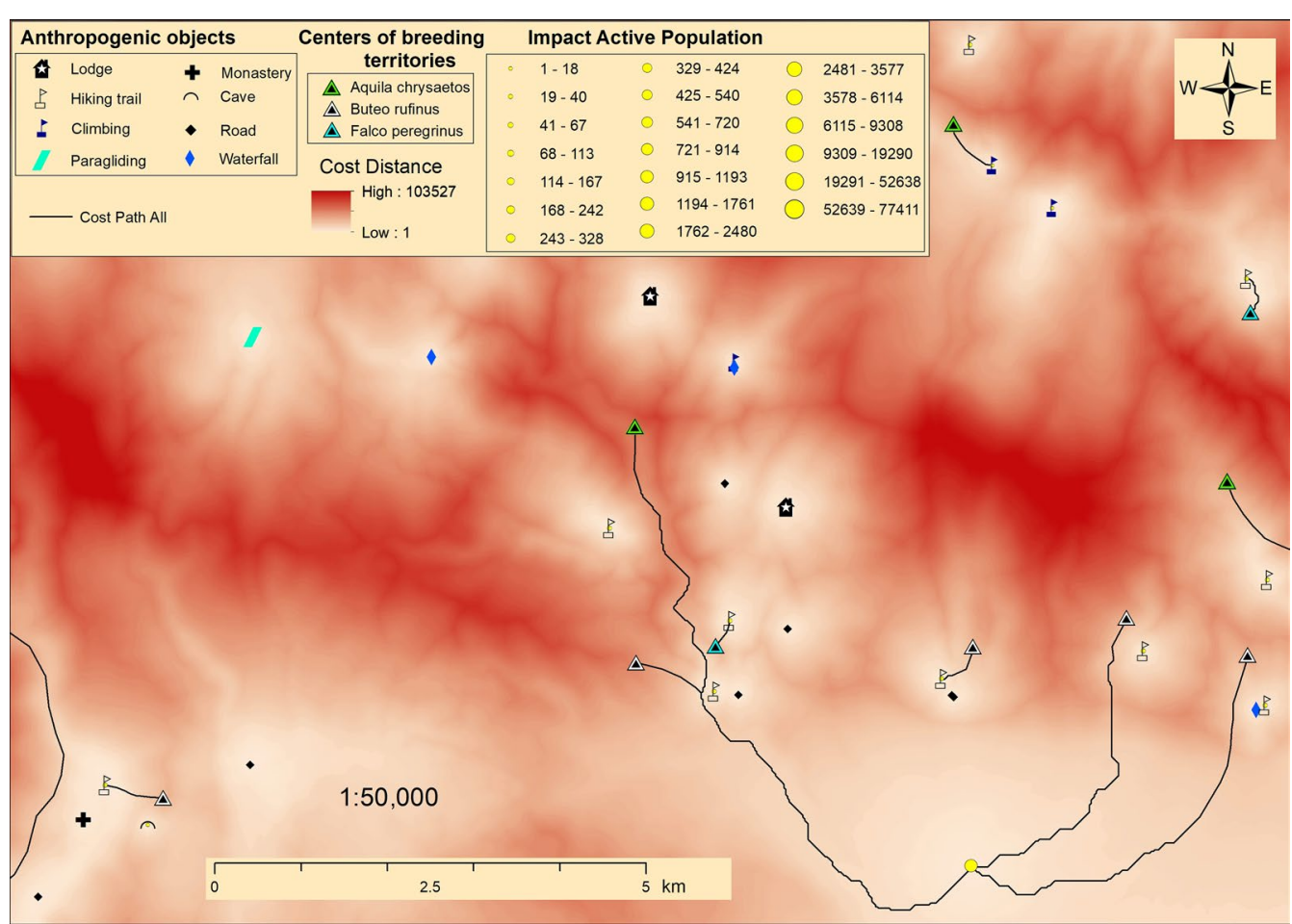

Fig. 3 Map of a sample section of the study area presenting the results obtained using Cost Path. The centers of the breeding territories are virtual points obtained after a deliberate change of the real location in order to prevent illegal actions on the protected species

one-way ANOVA was used in comparing requirements for the location of breeding territories of the three species in terms of accessibility. Cluster analysis was used to classify anthropogenic objects into relative groups.

\section{Results}

For all three species, the maximum mean cost path belonged to quarries and mines, suggesting that they would also have the lowest potential impact on the 
Table 3 Descriptive statistics of the cost path values of various impact points (anthropogenic objects) calculated for all three species under study

\begin{tabular}{|c|c|c|c|c|c|c|c|c|c|c|c|c|}
\hline \multirow{2}{*}{$\begin{array}{l}\text { Cost path } \\
\text { Impact points }\end{array}$} & \multicolumn{4}{|c|}{ Aquila chrysaetos ( $n=38)$} & \multicolumn{4}{|c|}{ Buteo rufinus ( $n=54$ ) } & \multicolumn{4}{|c|}{ Falco peregrinus $(n=20)$} \\
\hline & Mean & Min & Max & SD & Mean & Min & Max & SD & Mean & Min & Max & SD \\
\hline & & & & & & 5587 & & 39,839 & 75,266 & 22,156 & 223,431 & 47,958 \\
\hline Lodges & 572,636 & & $1,005,450$ & 233,616 & & & 6,020 & 448 & 3,885 & 5,458 & 5,330 & 309,488 \\
\hline Road & 772,518 & 154,350 & $2,120,293$ & 536,853 & 405,925 & 16,532 & $1,535,778$ & 296,832 & 611,835 & 83,041 & 1995,407 & 510,412 \\
\hline Trail & 133,723 & 13,197 & 306,222 & 80,500 & 80,627 & 4863 & 265,758 & 65,269 & 138,805 & 31,999 & 374,660 & 83,476 \\
\hline lines & \multicolumn{2}{|c|}{$2,352,757533,792$} & $5,816,220$ & $1,413,244$ & $4 \quad 1,585,221$ & 183,749 & $3,637,854$ & 840,781 & \multicolumn{2}{|c|}{$2,203,449213,645$} & $4,897,610$ & $1,195,14$ \\
\hline Religious & \multicolumn{2}{|c|}{$1,357,485177,925$} & \multicolumn{2}{|c|}{$2,818,153619,713$} & 920,064 & 90,372 & $2,138,050$ & 481,457 & \multicolumn{2}{|c|}{$1,456,415458,864$} & \multicolumn{2}{|c|}{$3,881,310768,204$} \\
\hline Recreation & 688,855 & 116,479 & $1,615,979$ & 371,224 & 534,988 & 18,901 & $1,397,080$ & 320,524 & 556,976 & 67,935 & $1,487,392$ & 361,736 \\
\hline All & 71,433 & 13,197 & 149,412 & 37,897 & 42,604 & 4863 & 130,039 & 30,751 & 64,827 & 22,390 & 128,624 & 33,508 \\
\hline
\end{tabular}

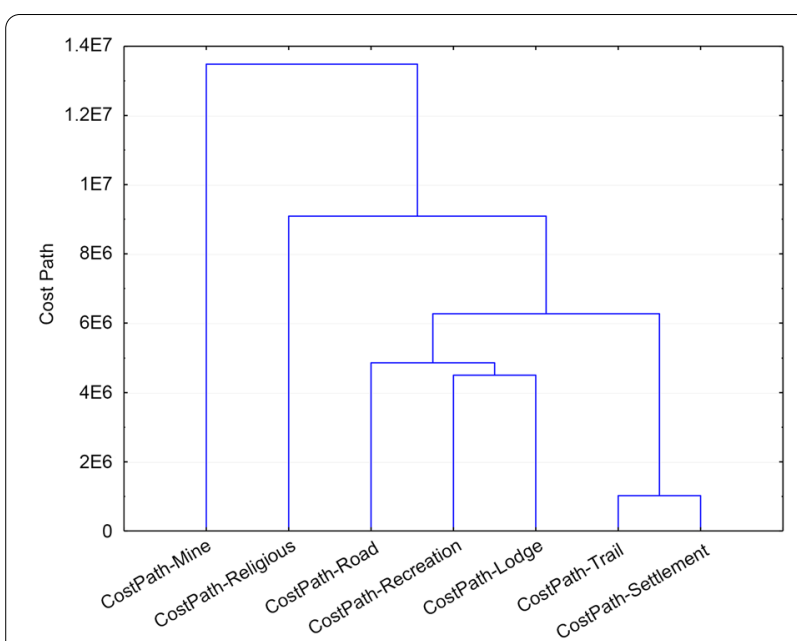

Fig. 4 Grouping of anthropogenic objects based on cost path values

breeding behavior of these breeding species. The greatest possible impact would be expected from settlements and tourist trails. The smallest cost path values were found for Long-legged Buzzard, indicating that the potential impact of the anthropogenic objects is strongest for this species. The maximum values of cost path were detected for the Golden Eagle, respectively, the potential impact of the anthropogenic objects is the least for this species (Table 3).

The results of the correlation analysis showed lack of correlation between the variables (Spearman $r<0.7$; $n=112 ; p<0.05)$.

Based on the cost path values, a grouping of the anthropogenic points is presented in Fig. 4.

The results of non-parametric one-way ANOVA are presented in Table 4. Comparing the three species, the most pronounced differences were found between the Long-legged Buzzard and the Golden Eagle. The selection of breeding territories in terms of accessibility in these two species differs significantly and reflects their different response in terms of human presence near the nest. The lack of statistically significant differences between the Peregrine Falcon and the Golden Eagle suggests that the two species exhibit very similar requirements for the

Table 4 Comparison of cost path values between Golden Eagle (GE), Long-legged Buzzard (LLB) and Peregrine Falcon (PF) using nonparametric one-way ANOVA

\begin{tabular}{|c|c|c|c|c|c|c|c|c|}
\hline \multirow{2}{*}{$\begin{array}{l}\text { Cost path } \\
\text { Impact points }\end{array}$} & \multirow{2}{*}{$\begin{array}{l}\text { Kruskal-Wallis test: } H \\
(2, n=112)\end{array}$} & \multirow[t]{2}{*}{$p$} & \multicolumn{2}{|c|}{ GE vs. LLB } & \multicolumn{2}{|c|}{ GE vs. PF } & \multicolumn{2}{|c|}{ LLB vs. PF } \\
\hline & & & $z$ & $p$ & $z$ & $p$ & $z$ & $p$ \\
\hline Settlement & 9.418431 & 0.0090 & $3.0616^{\mathrm{a}}$ & $0.0066^{\mathrm{a}}$ & 1.1874 & 0.7052 & 1.2234 & 0.6635 \\
\hline Lodge & 8.924810 & 0.0115 & $2.5767^{a}$ & $0.0299^{a}$ & 0.1910 & 1.0000 & 2.2858 & 0.0668 \\
\hline Road & 14.09659 & 0.0009 & $3.7219^{a}$ & $0.0006^{\mathrm{a}}$ & 1.2334 & 0.6522 & 1.7090 & 0.2624 \\
\hline Trail & 15.21118 & 0.0005 & $3.3937^{a}$ & $0.0021^{a}$ & 0.1898 & 1.0000 & $2.9455^{\mathrm{a}}$ & $0.0097^{a}$ \\
\hline Quarry/mine & 7.910001 & 0.0192 & $2.5139^{a}$ & $0.0358^{a}$ & 0.0047 & 1.0000 & 2.0286 & 0.1275 \\
\hline Religious & 16.75166 & 0.0002 & $3.5105^{a}$ & $0.0013^{a}$ & 0.3001 & 1.0000 & $3.1563^{a}$ & $0.0048^{a}$ \\
\hline Recreation & 5.810528 & 0.0546 & 2.3489 & 0.0565 & 1.5452 & 0.3669 & 0.2693 & 1.0000 \\
\hline All & 18.41045 & 0.0001 & $4.0845^{a}$ & $0.0001^{a}$ & 0.6638 & 1.0000 & $2.6034^{a}$ & $0.0277^{a}$ \\
\hline
\end{tabular}

${ }^{a}$ Denotes statistically significant differences between species 
location of breeding territories in terms of accessibility (Table 4).

The analyses on the distribution of the Golden Eagle, Long-legged Buzzard and Peregrine Falcon breeding territories in the Natura 2000 zones and the Protected Areas in the Balkan Mountains (Fig. 5) showed that Natura 2000 zones covered 84\% of the Golden Eagle territories, $81 \%$ of the Long-legged Buzzard and $90 \%$ of the Peregrine Falcon territories. The Protected Areas were found to include $50 \%, 29 \%$ and $60 \%$ respectively of the territories of the three studied species of raptors.

\section{Discussion}

Using the average cost path, we segregated anthropogenic effects into the three groups. Group one encompassed quarries, mines and religious centres. Group two included lodges, roads and recreational activity starting points while group three included settlements and pedestrian routes. The anthropogenic objects of the group one had the highest cost path values for all three bird species. Those were "the highest cost anthropogenic objects", meaning that the centers of the breeding territories were the most difficult to access from those points. Hence, quarries, mines, and religious tourism centers had the least impact and the lowest degree of significance as a source of anthropogenic invasion to the breeding territories. The anthropogenic objects of the group two were characterized by similar but lower cost path values. The anthropogenic objects of the group three had the lowest cost path values, i.e. those were "the least cost anthropogenic objects". The centers of the breeding territories were the most easily accessible from those points, hence they were considered to be the most significant and the most affecting the three bird species in the surveyed area. This was also supported by Cost Path All analysis of the united layer including all anthropogenic objects.

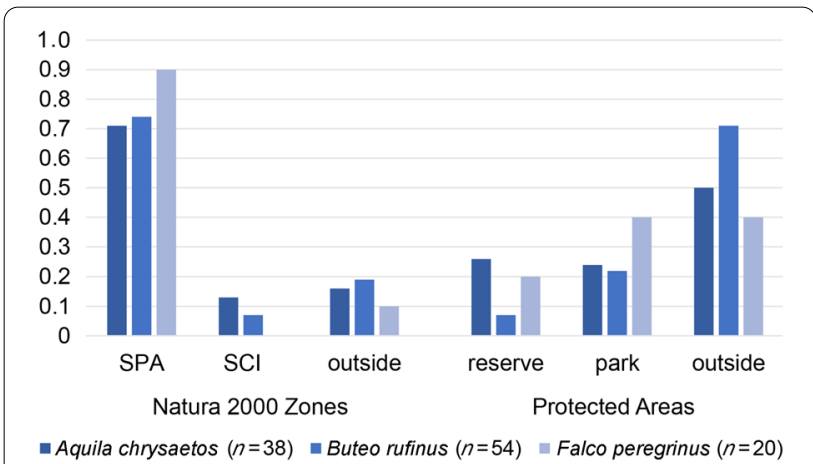

Fig. 5 Distribution of the breeding territories of the Golden Eagle, the Long-legged Buzzard and the Peregrine Falcon in the Natura 2000 Zones (SPA - Special Protected Areas; SCI - Sites of Community Importance) and the Protected Areas
Golden Eagle is characterized as sensitive to human disturbance (Andersen et al. 1990; Watson 1997). The species positions its breeding territories to avoid the proximity of anthropogenic effects. Shafaeipour (2015) suggests that the Golden Eagle selects cliffs that are remote from roads and settlements for nesting. Evidence indicates that easily accessible nesting sites are more vulnerable with higher breeding failure in comparison to those that are more difficult to access (Watson and Dennis 1992). Tourism expansion has steadily increased indirect disturbance within breeding territories (Perona et al. 2019). Recreational activities such as rock climbing, paragliding, mountain biking and snowboarding may increase breeding failure and reduce the foraging habitat available for Golden Eagles (Spaul and Heath 2016). Reduced foraging area increases the energy budget required by adult eagles and predisposes nestlings to increased predation (Tjernberg 1983; Pedrini and Sergio 2001). Proportionally, occupied territories decrease near tourist destinations (Kaisanlahti-Jokimäki et al. 2008). The territories occupied by Golden Eagle are characterized for the most part by low levels of disturbance (Xirouchakis 2001; Tapia et al. 2008) and a low density of the human population (Vazhov 2012). In the present study, the highest mean values of the cost path for Golden Eagle, as well as the highest mean values of the Cost Path All, characterized it as the species with the lowest degree of tolerance to human presence, occupying the most difficult to access territories. The major parts of the breeding territories of Golden Eagle (84\%) in the Balkan Mountains were found to be within Natura 2000 zones and only half of the territories were covered by protected areas. That is very insufficient, given the high conservation status of the species in Bulgaria, the sensitivity of Golden Eagle to anthropogenic factors and the fact that $46.7 \%$ of its national population resides in the Balkan Mountains (Vatev et al. 2015; Petrov et al. 2015).

The lowest average values of the cost path in the Balkan Mountains were established for Long-legged Buzzard for all anthropogenic objects, except for the lodges. The highest cost path values for the lodges for Long-legged Buzzard probably due to the specifics of the location of the lodges and it is an accidental departure from the general trend observed in this species. We believe that the occupation of breeding territories by the Long-legged Buzzard is not a function of disturbance from lodges. The results of the Cost Path analysis suggested that Longlegged Buzzard used to set its breeding territories in the most easily accessible by human's zones of the studied area compared to the other two species, so Long-legged Buzzard could be considered as the most tolerant to human presence. The major parts of the breeding territories of Long-legged Buzzard (81\%) were found to be 
within Natura 2000 zones and only $29 \%$ of the territories were covered by protected areas. That is very insufficient, given the high conservation status of the species in Bulgaria and that the bulk of the European Long-legged Buzzard population lives on the Balkan Peninsula (Mrlik and Landsfeld 2002; Stoychev and Demerdzhiev 2020).

Although Peregrine Falcon had been reported to breed in settlements and quarries (Moore et al. 1992, 1997; Crick and Ratcliffe 1995; Cade et al. 1996; Emison et al. 1997; Stoyanov 2003; Brambilla et al. 2006), the calculated average cost path values in this study were relatively high for the species. The average cost path values ranked Peregrine Falcon by its tolerance to human presence in an intermediate position compared to the other two species, but closer to those reported for Golden Eagle. This could be a result of the persecution of the species in Bulgaria for decades until the second half of twentieth century (Ragyov et al. 2008). Most of the breeding territories of Peregrine Falcon (90\%) were found to be within Natura 2000 zones and $60 \%$ of the breeding territories are in protected areas, placing this species in a better situation than the other two. Perhaps the fact that more breeding territories of the species are in protected areas has a positive effect on the population recovery observed in recent years (Stoynov et al. 2007; Ragyov et al. 2008).

\section{Conclusions}

The Long-legged Buzzard establishes its breeding territories in the most easily accessible zones, so this species could be considered as the most tolerant to disturbance. Long-legged Buzzard proved to be the most adaptive to anthropogenic presence in its breeding habitats, which could be considered as an advantage to support the range expansion of the species over the last decades. The Golden Eagle is the species with the lowest degree of tolerance, occupying the most difficult territories in terms of human access. Golden Eagle avoided proximity to humans to the highest degree, which identified it as the most sensitive to anthropogenic invasion in its breeding habitat. The Peregrine Falcon is ranked in an intermediate position compared to the other two species. The lack of statistically significant differences between Peregrine Falcon and Golden Eagle suggested that, regarding its response towards human presence in its territory, Peregrine Falcon was closer to Golden Eagle. Natura 2000 coverage is favorable for all three species-most of their breeding territories fall into Natura 2000 zones. The location of the breeding territories of the three species of interest in protected parks and reserves proved to be insufficient, the situation with Golden Eagle and Longlegged Buzzard being particularly adverse. It is recommended that all the permanently occupied territories of
Golden Eagle, Long-legged Buzzard, and Peregrine Falcon be included in the system of the protected areas.

\section{Acknowledgements}

The authors express their gratitude to PhD Svetlana Naumova for polishing up the English version of the manuscript.

\section{Authors' contributions}

$D R, V B$ and ND conceived and designed the study. DR and ND performed the field work. ND, JB and VB processed and analyzed the data. ND wrote the manuscript. VB and BPN made comments to the manuscript. VB, BPN and ND read and approved the manuscript. All authors read and approved the final manuscript.

\section{Funding}

The work was not funded by any specific body.

\section{Availability of data and materials}

The coordinates of the centers of breeding territories will not be made available for public access in order to prevent unscrupulous action on the protected species.

\section{Declarations}

Ethics approval and consent to participate

This work complies with the current laws of Bulgaria. It was based on simple field observation without any experimental manipulation or damage to the studied birds.

\section{Consent for publication}

Not applicable.

Competing interests

The authors declare that they have no competing interests.

Received: 30 September 2020 Accepted: 30 May 2021

Published online: 09 June 2021

\section{References}

Alivizatos H, Goutner V, Karandinos MG. Reproduction and behaviour of the Long-legged Buzzard (Buteo rufinus) in North-eastern Greece. Die Vogelwarte. 1998;39:176-82.

Andersen DE, Rongstad OJ, Mytton WR. Home range changes in raptors exposed to increased human activity levels in southeastern Colorado. Wildl Soc Bull. 1990:18:134-42.

Boev N. Données sur l'étendue de l'aire d'habitat estivale de certaines espèces d'oiseaux en Bulgarie. Bull de l'Institut de Zoologie et Musée, BAS. 1962;11:31-46 (in Bulgarian, summary in French).

Brambilla M, Rubolini D, Guidali F. Factors affecting breeding habitat selection in a cliff-nesting peregrine Falco peregrinus population. J Ornithol. 2006;147:428-35.

Cade T, Martell M, Redig P, Septon G, Tordoff H. Peregrine Falcons in urban north America. In: Bird D, Varland D, Negro J, editors. Raptor in human landscapes: adaptation to built and cultivated environments. San Diego: Academic Press; 1996. p. 3-13.

Carrete M, Tella JL, Blanco G, Bertellotti M. Effects of habitat degradation on the abundance, richness and diversity of raptors across Neotropical biomes. Biol Conserv. 2009;142:2002-11.

Crick HQP, Ratcliffe DA. The Peregrine Falco peregrinus breeding population of the United Kingdom in 1991. Bird Study. 1995;42:1-19.

Demerdzhiev D, Dobrev V, Popgeorgiev G. Effects of habitat change on territory occupancy, breeding density and breeding success of Longlegged Buzzard (Buteo rufinus Cretzschmar, 1927) in Besaparski Ridove Spatial Protection Area (Natura 2000), southern Bulgaria. Acta Zool Bulg. 2014;5(Suppl):191-200. 
Emison WB, White CM, Hurley VG, Brimm DJ. Factors influencing the breeding distribution of the peregrine falcon in Victoria, Australia. Wildlife Res. 1997;24:433-44.

Esteves CF, de Barros Ferraz SF, de Barros Ferraz KM, Galetti M, Theobald DM. Human accessibility modelling applied to protected areas management. Nat Conservação. 2011;9:232-9.

Fernández JM, Gurrutxaga M. Habitat suitability models for assessing bird conservation goals in spatial protection areas. Ardeola. 2010;57:79-91.

Gainzarain JA, Arambarri R, Rodríguez AF. Breeding density, habitat selection and reproductive rates of the Peregrine falcon Falco pererinus in Alava (northern Spain). Bird Study. 2000;47:225-31.

Greenwood JJD. Basic techniques. In: Sutherland WJ, editor. Ecological census techniques. Cambridge: Cambridge University Press; 1996. p. 11-110.

Gruev B, Kuzmanov B. General Biogeography. Sofia: University Press; 1994. (in Bulgarian).

Jenkins AR. Hunting mode and success of African Peregrines Falco peregrinus minor: does nesting habitat quality affect foraging efficiency? Ibis. 2000;142:235-46.

Jenkins AR, van Zyl AJ. Conservation status and community structure of cliffnesting raptors and ravens on the Cape Peninsula. South Africa Ostrich. 2005;76:175-84.

Jobe RT, White PS. A new cost-distance model for human accessibility and an evaluation of accessibility bias in permanent vegetation plots in Great Smoky Mountains National Park, USA. J Veg Sci. 2009;20:1099-109.

Kaisanlahti-Jokimäki ML, Jokimäki J, Huhta E, Ukkola M, Helle P, Ollila T. Territory occupancy and breeding success of the Golden Eagle (Aquila chrysaetos) around tourist destinations in northern Finland. Ornis Fennica. 2008;85:2-12.

Karyakin IV, Nikolenko EG. Peregrine Falcon in the Altai-Sayan Region. Russia Raptors Conserv. 2009;16:96-128.

Kopralev I. Geography of Bulgaria. Publisher For Com; 2002 (in Bulgarian).

LaRue MA, Nielsen CK. Modelling potential dispersal corridors for cougars in midwestern North America using least-cost path methods. Ecol Model. 2008;212:372-81.

Michev T, Vatev IT, Simeonov PS, Profirov L. Distribution and Nesting of the Long-Legged Buzzard (Buteo rufinus (Cretzchmar, 1827) in Bulgaria. Ecology. 1984;13:74-82 (in Bulgarian).

Milchev B. Breeding bird atlas of the Strandja mountains, south-east Bulgaria. Sandgrouse. 1994;16:2-27.

Milchev B. Breeding biology of the Long-legged Buzzard Buteo rufinus in SE Bulgaria, nesting also in quarries. Avocetta. 2009;33:25-32.

Milchev B, Georgiewa U. Eine Studie zum Bestand, zur Brutbiologie und Ernährug des Steinadlers, Aquila chrysaetos (L.) im Strandsha - Gebirge. Beitr Vogelkd. 1992;38:327-34.

Minetti AE, Moia C, Roi GS, Susta D, Ferretti G. Energy cost of walking and running at extreme uphill and downhill slopes. J Appl Physiol. 2002:93:1039-46.

Moore N, Kelly P, Lang F. Quarrynesting by Peregrine falcons in Ireland. Irish Birds. 1992;4:519-24.

Moore NP, Kelly PF, Lang FA, Lynch JM, Langton SD. The Peregrine Falco peregrinus in quarries: current status and factors influencing occupancy in the Republic of Ireland. Bird Study. 1997:44:176-81.

Mrlik V, Landsfeld B. The occurrence of Long-legged Buzzard (Buteo rufinus) in parts of Central Europe during 1980-1998 and possible factors for its recent expansion. Egretta. 2002;45:104-14.

Newton I. Population ecology of raptors. Berkhamsted:T \& AD Poyser; 1979.

Nikolov I. Photo guide of Bulgarian waterfalls. Sofia: Biko Bulgaria; 2013.

Pedrini P, Sergio F. Density, productivity, diet and human persecution of Golden eagles (Aquila chrysaetos) in the central-eastern Italian Alps. J Raptor Res. 2001;35:40-8.

Perona AM, Urios V, López-López P. Holidays? Not for all. Eagles have larger home ranges on holidays as a consequence of human disturbance. Biol Conserv. 2019;231:59-66.

Petrov T, Tonchev B, Demerdjiev D, Daskalova G, Stoynov E. Golden eagle (Aquila chrysaetos). In: Atlas of the breeding birds in Bulgaria. Conservation series/book 10. Sofia: BSPB; 2007 (in Bulgarian).

Petrov TS, Spiridonov J, Domuschiev D, Kurtev M. Golden Eagle (Aquila chrysaetos, Linnaeus, 1758). In: Red data book of the Republic of Bulgaria, Vol 2. Animals. Sofia: BAS \& MOEW; 2015 (in Bulgarian).
Ragyov D, Demerdzhiev D, Angelov I. Peregrine in Bulgaria - general overview. In: Sielicki J, Mizera T, editors. Peregrine Falcon populations - status and perspectives in the 21st century. Turul, Warsaw: European Peregrine Falcon Working Group, Society for the Protection of Wild Animals "Falcon"; 2008. p. 345-60.

Redinov KO. Ecology of the Long-legged Buzzard in Mykolayiv region (Southern Ukraine). Berkut. 2010;19:116-32 (in Russian).

Russo D. Effects of land abandonment on animal species in Europe: conservation and management implications. Luxembourg: Office for Official Publications of the EuropeanCommunities; 2006.

Schadt S, Knauer F, Kaczensky P, Revilla E, Wiegand T, Trepl L. Rule-based assessment of suitable habitat and patch connectivity for the Eurasian lynx. Ecol Appl. 2002;12:1469-83.

Sergio F, Newton I, Marchesi L, Pedrini P. Ecologically justified charisma: preservation of top predators delivers biodiversity conservation. J Appl Ecol. 2006:43:1049-55

Sergio F, Rizzoli F, Marchesi L, Pedrini P. The importance of interspecific interactions for breeding-site selection: peregrine falcons seek proximity to raven nests. Ecography. 2004;27:818-26.

Shafaeipour A. Breeding success and nest characteristics of Golden Eagle Aquila chrysaetos in western Iran. Acta Zool Bulg. 2015;67:299-302.

Simeonov S, Michev T, Nankinov D. Fauna of Bulgaria, Vol. 20 Aves, Part I. Sofia: BAS; 1990 (in Bulgarian).

Spaul RJ, Heath JA. Nonmotorized recreation and motorized recreation in shrub-steppe habitats affects behavior and reproduction of golden eagles (Aquila chrysaetos). Ecol Evol. 2016;6:8037-49.

Spaul RJ, Heath JA. Flushing responses of Golden Eagles (Aquila chrysaetos) in response to recreation. Wilson J Ornithol. 2017;129:834-45.

Stoyanov G. Peregrine falcon (Falco peregrinus). Acrocephalus. 2003;24:41-2.

Stoyanov GP, Borisov B, Antonov A, Domuschiev D, Petrov T. Peregrine Falcon (Falco peregrinus, Tunstall, 1771). In: Golemanski V, editor. Red data book of the Republic of Bulgaria. Animals, vol. 2. Sofia: BAS \& MOEW; 2015 (in Bulgarian)

Stoychev S, Demerdzhiev D, et al. Long-legged Buzzard Buteo rufinus. In: Keller V, Herrando S, Vořišek P, Franch M, Kipson M, Milanesi P, et al., editors. European breeding bird atlas 2: distribution, abundance and change. Barcelona: European Bird Census Council \& Lynx Editions; 2020. p. 480.

Stoynov E, Petrov T, Tonchev B, Ruskov K, Hristov H, Profirov L. Peregrine Falcon (Falco peregrinus). In: Atlas of the breeding birds in Bulgaria. Conservation series/book 10. Sofia: BSPB; 2007. p. 188-9 (in Bulgarian).

Tapia L, Domínguez J, Rodríguez L. Hunting habitat preferences of raptors in a mountainous area (Northwestern Spain). Pol J Ecol. 2008;56:323-33.

Tjernberg M. Habitat and nest site features of golden eagles Aquila chrysaetos (L.), in Sweden. Swed Wildl Res. 1983;12:131-63.

Trombulak SC, Frissell CA. Review of ecological effects of roads on terrestrial and aquatic communities. Conserv Biol. 2000;14:18-30.

Vatev I. Notes on the breeding biology of the Long-legged Buzzard (Buteo rufinus) in Bulgaria. J Raptor Res. 1987;21:8-13.

Vatev I, Angelov I, Domuschiev D, Profirov L. Long-legged Buzzard (Buteo rufinus, Cretzschmar, 1827). In: Red data book of the Republic of Bulgaria. Animals, vol. 2. Sofia: BAS \& MOEW; 2015 (in Bulgarian).

Vazhov SV. Some features of the ecological niches of raptors in the Russian part of the altai foothills. Raptors Conserv. 2012:25:115-25 (in Russian).

Watson J, Dennis RH. Nest-site selection by Golden Eagles Aquila chrysaetos in Scotland. British Birds. 1992;85:469-81.

Watson J. The Golden Eagle and pastoralism across Europe. In: Curtis DJ, Bignal EM, Curtis MA, editors. Birds and pastoral agriculture in Europe. Peterborough: JNCC; 1991. p. 56-7.

Watson J. Golden Eagle Aquila chrysaetos breeding success and afforestation in Argyll. Bird Study. 1992;39:203-6.

Watson J. The golden eagle. London: T \& AD Poyser; 1997.

Whitfield DP, Fielding AH, Gregory MJP, Gordon AG, McLeod DRA, Haworth PF. Complex effects of habitat loss on Golden Eagles Aquila chrysaetos. Ibis. 2007;149:26-36.

Xirouchakis S. The Golden Eagle Aquila chrysaetos in Crete. Distribution, population status and conservation problems. Avocetta. 2001;25:275-81. 